\title{
Estimation of zinc levels among children with malnutrition at Usmanu Danfodiyo University Teaching Hospital, Sokoto, Northwestern Nigeria
}

\author{
*Adamu Asma'u , Jiya Mohammed N., Ahmed Hamidu, Ibitoye Paul K., Ugege Modupe \\ O., Sani Usman M., Yusuf Tahir, Jiya Fatima B., Isezuo Khadijat $O$.
}

\begin{abstract}
Objective: Zinc plays a critical role in many body functions and its deficiency is associated with impaired cognitive function, behavioral problems, memory impairment, growth retardation, increased incidence of diarrhoea and recurrent infections. Although severe zinc deficiency is not common, mild to moderate deficiency is quite common globally. It is estimated that some form of zinc deficiency affects about one third of the world population, with estimates ranging from $4 \%$ to $73 \%$ across sub Saharan Africa. To determine the prevalence of zinc deficiency among malnourished children at Usmanu Danfodiyo University Teaching Hospital (UDUTH), Sokoto.
\end{abstract}

Methods: Study was descriptive cross-sectional, carried out at the Paediatric department of UDUTH, Sokoto from April 2013 to June 2014. It was conducted among children aged between 6 and 60 months who presented to the OPD and those that were admitted into paediatric wards of UDUTH with malnutrition. Children with similar characteristics that were well nourished served as controls. Cohorts were recruited consecutively until the required sample size was obtained. $5 \mathrm{mls}$ of venous blood was taken for serum zinc analysis from each child.

Results: A total of 550 children were studied with 275 apiece for cohorts. The mean age of the malnourished children was $26.2 \pm 14.6$ months compared to $28.2 \pm 17.0$ months recorded for the controls $(\mathrm{p}=0.157)$.The mean serum zinc levels for the study subjects $13.5 \pm 3.3 \mu \mathrm{mol} / \mathrm{L}$ was significantly lower than that of the controls $(15.8 \pm 1.9 \mu \mathrm{mol} / \mathrm{L})(\mathrm{t}=9.42, \mathrm{df}=548, \mathrm{p}=0.0001)$.

Conclusion: The prevalence of zinc deficiency among both malnourished children and the controls was $0 \%$ using WHO reference value for children below the age of 5 years. Prophylactic doses of zinc should be given in all malnourish children in situation where mineral mix is not added to feed or $\mathrm{f} 75$ and $\mathrm{f} 100$ are not available. There is need to adhere to and use recommended cut off values recommended by WHO for defining zinc deficiency by researchers.

Key words: zinc, malnutrition, Sokoto

*Correspondence Author: Dr. Adamu A., Email: nanadamu@ gmail.com

Department of Paediatrics, Usmanu Danfodiyo University Teaching Hospital, Sokoto, Nigeria.

Research Journal of Health Sciences subscribed to terms and conditions of Open Access publication. Articles are distributed under the terms of Creative Commons Licence (CC BY-NC-ND 4.0). (http://creativecommons.org/licences/by-nc-nd/4.0).

http://dx.doi.org/10.4314/rejhs.v4i4.3 


\title{
Estimation du taux de zinc chez les enfants atteints de malnutrition à l'hôpital universitaire Usmanu Danfodiyo, Sokoto, Nord-Ouest du Nigeria
}

\author{
*Adamu Asma'u , Jiya Mohammed N., Ahmed Hamidu, Ibitoye Paul K., Ugege Modupe \\ O., Sani Usman M., Yusuf Tahir, Jiya Fatima B., Isezuo Khadijat O.
}

\begin{abstract}
Resume
Objectif: Le zinc joue un rôle critique dans de nombreuses fonctions corporelles et sa carence est associée à une déficience de la fonction cognitive, des problèmes de comportement, des troubles de la mémoire, un retard de croissance, une incidence accrue de diarrhée et des infections récurrentes. Bien que la carence en zinc sévère n'est pas commune, une carence légère à modérée est assez commune dans le monde. On estime qu'une certaine forme de carence en zinc affecte environ un tiers de la population mondiale, avec des estimations allant de $4 \%$ à $73 \%$ dans l'Afrique subsaharienne. Déterminer la prévalence de la carence en zinc chez les enfants souffrant de malnutrition à l'hôpital universitaire Umanu Danfodiyo (UDUTH), à Sokoto.
\end{abstract}

Méthodes: L'étude a été descriptive transversale, réalisée au département pédiatrique de l'UDUTH, à Sokoto d'avril 2013 à juin 2014. Elle a été menée chez des enfants âgés de 6 à 60 mois qui ont présenté à l'OPD et ceux qui ont été admis dans les services de pédiatrie De UDUTH avec malnutrition. Les enfants ayant des caractéristiques similaires qui ont été bien nourris contrôles servedas.Cohorts ont été recrutés consécutivement jusqu'à ce que la taille de l'échantillon requis a été obtenue. $5 \mathrm{ml}$ de sang veineux ont été prélevés pour l'analyse du sérum zinc de chaque enfant.

Résultats: Un total de 550 enfants ont été étudiés avec 275 chacun pour les cohortes. L'âge moyen des enfants sous-alimentés était de 26.214,6 mois comparativement à 28.217 .0 mois pour les témoins ( $\mathrm{p}=$ 0.157). Les taux moyens de zinc sérique pour les sujets de l'étude $13.5 \pm 3.3 \mu \mathrm{mol} / \mathrm{L}$ etaient significativement inferieurs a ceux des temoins $(15,8 \pm 1,9 \mu \mathrm{mol} / \mathrm{L})(\mathrm{t}=9,42, \mathrm{df}=548, \mathrm{p}=0,0001)$.

Conclusion: La prevalence de la carence en zinc chez les enfants malnutris et les temoins etait de 0\% en utilisant la valeur de reference de l'OMS pour les enfants de moins de 5 ans. Des doses prophylactiques de zinc devraient etre administrees a tous les enfants malnutris, Les aliments pour animaux ou f 75 et f100 ne sont pas disponibles.Il faut respecter et utiliser les valeurs de coupure recommandees par l'OMS pour definir la carence en zinc par les chercheurs.

Mots cles: zinc, malnutrition, Sokoto

*Auteur correspondant:Dr. Adamu A, Email: nanadamu@ gmail.com

Department of Paediatrics, Usmanu Danfodiyo University Teaching Hospital, Sokoto, Nigeria. 


\section{INTRODUCTION}

Protein energy malnutrition (PEM) is highly prevalent in almost all developing countries $(1,2)$. It is estimated to affect every third child in the developing world. $(3,4)$ About $1-7 \%$ of under-five children suffer from the severe forms of malnutrition like kwashiorkor and marasmus $(5,6)$. This small percentage of severe forms identified is an indication that larger number of mild and moderate malnutrition occurred unrecognised. Globally, it is estimated that there are nearly 20 million children who are severely acutely malnourished; most of them live in south Asia and in sub-Saharan Africa (7). In Africa, the prevalence for the moderate forms of PEM is $5.4-44.9 \%$ and $1.7-9.8 \%$ for severe forms $(8,9)$. Although severe zinc $(\mathrm{Zn})$ deficiency is not common, mild to moderate deficiency is quite common throughout the world (10). It is estimated that some form of Zn deficiency affects about one third of the world population, with estimates ranging from $4 \%$ to $73 \%$ across sub Saharan Africa (11).

Zinc has been known to be an essential element since its discovery by Raulin in 1869 $(12,13)$. It is a trace element that is essential for normal growth and development of infants and children, $\mathrm{Zn}$ is found in bones, teeth, hair, skin, muscle and testis. Of the $\mathrm{Zn}$ in the blood, about $75-85 \%$ is in the erythrocytes almost wholly as carbonic anhydrase for which it is a cofactor $(14,15)$. Plasma has about $12-22 \%$, while white cells has $3 \% .98 \%$ of $\mathrm{Zn}$ is intracellular (16).

Zinc deficiency in malnourished children could be due to low dietary intake, poor bioavailability, malabsorption, or increased losses due to diarrhoea along with lack of or inadequate breastfeeding (17). The nature and type of foods used during weaning and the low levels of zinc in breast milk may also contribute to the low levels of zinc in malnourished children (17). In children with severe PEM and those growing rapidly, the serum zinc levels falls drastically, unless zinc supplements are given (18). Zinc deficiency in severe PEM can be explained by gross hypo-albuminemia that contributes to lower serum zinc levels (17). Increased loss of zinc from the skin has also been suggested and this further contributes to the lowered levels of zinc in severe PEM (12).

Besides nutritional factors, many diseases and medical treatments may produce conditional $\mathrm{Zn}$ deficiency, including tuberculosis, sickle cell disease, Wilson's disease, diabetes mellitus and other severe chronic infections (14). The deficiency is more common in regions with high consumption of rice and unleavened bread as dietary fibre, this is because phytate inhibit $\mathrm{Zn}$ absorption (14). The effects of its deficiency are especially pronounced in tissues and organs with rapid turnover such as the immune system and during periods of rapid growth (13). $\mathrm{Zn}$ deficiency has of late been gaining more attention from researchers and developmental organisations (10). This is because $\mathrm{Zn}$ plays a critical role in many body functions and its deficiency is associated with impaired cognitive function, behavioural problems, memory impairment, growth retardation, increased incidence of diarrhoea and recurrent infections (19).

In Nigeria, Ugwuja et al (20) studied serum $\mathrm{Zn}$ and copper levels among malnourished pre- school age children in Jos, North central Nigeria. The study showed significantly reduced serum zinc levels among malnourished compared to well-nourished children. Similarly, a study by Okolo et al (17) at Jos University Teaching Hospital showed low mean serum $\mathrm{Zn}$ levels among the malnourished group of children studied. The study demonstrated that the mean serum $\mathrm{Zn}$ level was lowest in children with kwashiorkor. Zn status in malnourished Nigerian children has also been evaluated in several other studies, $(16-17,20)$ however, none was conducted in the North-Western region of the country. The study therefore was designed to determine the prevalence of $\mathrm{Zn}$ deficiency among children with malnutrition seen in UDUTH, Sokoto and compare serum levels of $\mathrm{Zn}$ between malnourished children and age matched wellnourished children. We seek to provide local data from the North-Western region on this subject. This will enable comparison with other studies and will go a long way in making policies towards improving the quality of care for such children.

\section{MATERIALSAND METHODS}

This was a descriptive, cross-sectional study carried out at the paediatric department of the Usmanu Danfodiyo University Teaching Hospital (UDUTH), a tertiary health facility located in Sokoto, the Sokoto State capital, North-western Nigeria. The hospital is a referral centre for people from Sokoto, Zamfara, Niger, Katsina and Kebbi States of Nigeria as well as neighbouring Niger and Benin Republics.

Study Design:The study was conducted among children aged between 6 and 60 months who presented with malnutrition to the Paediatric Units comprising [Emergency Paediatric Unit 
(EPU), Paediatric Outpatient Clinic (POPD) and Paediatric Medical Ward (PMW)] of UDUTH, Sokoto. Controls were well-nourished apparently healthy children that attended POPD for follow up after discharge from the hospital. Subjects and controls were recruited consecutively between April 2013 to June 2014 until the required sample size was obtained.

Inclusion criteria:Inclusion criteria for recruited study subjects were age range 6 to 60 months, presence of malnutrition according to the $\mathrm{WHO}$ classification of malnutrition: $<-1$ to $<-3 \mathrm{Z}$ scores of WHO reference growth charts (21), obtained written informed consent from parent or caregiver. Greater than $-1 \mathrm{Z}$ score of the WHO child growth standard reference values for weight-for-length / height and length / height-forage (21) and similarly age range 6 to 60 months as well as obtained informed written consent were inclusion criteria for controls.

Children with all criteria (21) but presented with acute diarrhoea, features of respiratory tract infection, and sickle cell anaemia, Ingestion of zinc supplements in the preceding 3 months before the study and those that were stunted were excluded from the study.

The minimum sample size was determined using a standard formula (22).

$$
\mathrm{N}=\underline{\mathrm{z}^{2}} \underline{\mathrm{pq}}
$$

Where

$\mathrm{N}=$ desired sample size needed for meaningful statistical analysis

$\mathrm{z}=$ the standard normal deviate usually set at 1.96

which corresponds to $95 \%$ confidence interval. $\mathrm{p}=$ the proportion in the target population estimated to have a particular characteristics $\mathrm{q}=1-\mathrm{p}=1.0-0.078=0.922$

$\mathrm{d}=$ degree of accuracy desired. This was taken as $5 \%$ or 0.05

For this study, taking the prevalence of zinc deficiency in under five Nigerian children as $20 \%$ (23) ( $p$ value $=0.2$ ), the calculated minimum sample size was $246,10 \%$ attrition was 25,246 $+25=271$ approximated to 275.275 subjects each were selected for the study and control groups with a total of 550 participants for the study. All consecutive admissions into the EPU, PMW and children that attended POPD of UDUTH, Sokoto during the study period with diagnosis of malnutrition based on the WHO classification of malnutrition that fulfilled the inclusion criteria were enrolled into the study.

Questionnaire: A structured pretested questionnaire using interview method was used to obtain information from recruited subjects and controls on socio-demographic characteristics, and socio-economic class (SEC) of both parents using Oyedeji's classification (24). Other information included dietary history, preceding illnesses like measles and diarrhoeal disease. SEC II and I are the upper class, SEC III is the middle class, while SEC IV and V form the lower class (24).

All the children recruited for the study had detailed clinical examination to check presence or absence of oedema of the feet, dehydration, pyrexia, skin and hair changes. Relevant information was recorded using the study proforma. Anthropometric indices such as the weight and length were measured using standard procedure for all recruited children. Nutritional status of the recruited children was assessed using the WHO classification of malnutrition (21).

The subjects were classified as mild wasting (weight-for- height ratio between $<-1$ to $>-2 \mathrm{SD}$ ), moderate wasting (weight-for heightratio between $<-2$ to $>-3 \mathrm{SD}$ ) and severe wasting (weight-for- height ratio <-3 SD) (25) children that presented with bilateral oedema of the feet were categorised as oedematous malnutrition (25). Controls were well nourished children whose weight-for-height ratio were $>-1 \mathrm{SD}$ (21) and whose height-for-age ratio were +2SD to >1SD of the WHO child growth standards reference values (21). Standard deviation of weight- for- length/height for each recruited child was obtained by plotting the measured weight on WHO growth chart against the length/height and gender. Reference values were taken from the WHO child growth standards (21). Height for age $\mathrm{Z}$ score for each recruited child was obtained by plotting the measured length/ height against age on the WHO growth chart for gender.(21)

Laboratory methods: Five millilitres of blood was collected from each child by venopuncture after taking aseptic measures and immediately placed into a well-labelled specimen bottle without anticoagulant. The blood samples were immediately centrifuge at2000revolutions per minute for 5 minutes. Serum was relabelled and then frozen at $-20^{\circ} \mathrm{C}$ until time for the analysis. Serum $\mathrm{Zn}$ was determined by Atomic Absorption Spectrophotometry (AAS) using Buck Model 205 Atomic Absorption Spectrophotometer (Buck Norwalk, CL) by direct method as described by Kaneko et al (26).

For this study, serum zinc level of 
$<9.9 \mu \mathrm{mo} / \mathrm{L}$ was taken as cut off value for zinc deficiency, which is the WHO cut off value for zinc deficiency in children less than five years of age (27).

Data analysis was done using the Statistical Package for Social Sciences (SPSS) version 20.0 software. The results were illustrated using frequency tables and figures. Comparison of mean values of subjects and controls was done using Student's t test, while comparison of proportions was done using Chisquare test. A $p$-value of 0.05 or less was regarded as statistically significant.

\section{RESULTS \\ Demographic characteristics of the subjects and controls}

The mean age of the children with malnutrition was $26.2 \pm 14.6$ months compared to $28.2 \pm 17.0$ months in the controls. $(\mathrm{p}=0.157)$.Table I shows the age distribution of the subjects and controls. Two hundred and twenty five $(81.8 \%)$ of the children with malnutrition were between the ages of 6 and 36 months.Out of the 275 children with malnutrition, 137(49.8\%) were males and $138(50.2 \%$ ) were females (ratio 1:1), when compared to the control group with 152(55.3\%) males and 123(44.7\%) females (ratio $1: 1.2),(\mathrm{p}=0.0001)$.

\section{Mean weight for age of the subjects compared with controls.}

The mean weight for age was significantly lower in the study subjects compared to that of the controls. Figure 1 shows the mean weight for age centile curves for the subjects and controls compared with the median values of WHO weight for age growth chart. The centile curve for the subjects falls significantly below the median values of WHO weight for age growth chart whereas, that of the controls was comparable to it.

\section{Distribution of clinical types of malnutrition according to age groups.}

$93(33.8 \%)$ of the children with malnutrition had oedematous malnutrition, $82(29.8 \%)$ had severe wasting, while 30(10.9\%) and $70(25.4 \%)$ of the children had mild and moderate wasting respectively.

Oedematous malnutrition and severe wasting were more common among children aged 12 to 24 months, except for mild wasting which predominates at $48.1-60.0$ months age group, as shown on Table II.

\section{Mean serum zinc levels of the subjects and controls}

The mean serum $\mathrm{Zn}$ levels for the subjects were significantly lower $(13.5 \pm 3.3 \mu \mathrm{mol} / \mathrm{L})$ than that of the controls $(15.8 \pm 1.9 \mu \mathrm{mol} / \mathrm{L})(\mathrm{t}=9.42, \mathrm{df}=548, p=0.0001)$, but none was below the $\mathrm{Zn}$ deficiency state.

\section{Comparison of mean serum zinc levels between children with malnutrition and controls according to age.}

The mean serum $\mathrm{Zn}$ levels of malnourished children were significantly lower $(13.5 \pm 3.3 \mu \mathrm{mol} / \mathrm{L})$ than that of the control group $(15.8 \pm 1.9 \mu \mathrm{mol} / \mathrm{L})$. The difference was significant $(p=0.0001)$. The levels were also observed to be significantly low $(p=<0.05$ ) across all age categories of malnourished children compared with age-matched controls as shown on tableIII.It is not suprising that malnourished children in the age group 24.1-36.0 months had the lowest serum $\mathrm{Zn}$ levels $(12.8 \pm 2.5 \mu \mathrm{mol} / \mathrm{L})$, when compared with controls of the same age group $(15.3 \pm 2.4 \mu \mathrm{mol} / \mathrm{L})$, the difference was significant $(p=0.0001)$. Interestingly though, those within the age range48.1-60.0 months have the highest value of serum $\mathrm{Zn}(14.4 \pm 4.0 \mu \mathrm{mol} / \mathrm{L})$ (Table III).

Mean serum zinc levels of children with malnutrition and controls according to age and gender.

The mean serum $\mathrm{Zn}$ level of control males $(16.1 \pm 2.4 \mu \mathrm{mol} / \mathrm{L})$ was higher when compared to that of male subjects $(13.7 \pm 3.8 \mu \mathrm{mol} / \mathrm{L})$, the difference was significant $(p=0.0001)$. Likewise, significant gender difference was observed in the mean serum $\mathrm{Zn}$ levels of the control females $(15.3 \pm 1.5 \mu \mathrm{mol} / \mathrm{L})$ and malnourished females $(13.5 \pm 2.8 \mu \mathrm{mol} / \mathrm{L})$ $(p=0.0001)$. No significant gender differences were observed in the mean serum $\mathrm{Zn}$ levels across all age groups between malnourished males and control males as well as in malnourished females and controls females except for age group 12.124.0 among the males $(p<0.05)$ (Table IV).

\footnotetext{
Mean serum zinc levels of children with malnutrition according to age and gender

The mean serum $\mathrm{Zn}$ levels of males subjects $(13.7 \pm 3.8 \mu \mathrm{mol} / \mathrm{L})$ was similar to that of malnourished females $(13.5 \pm 2.8 \mu \mathrm{mol} / \mathrm{L})$, the difference was however not significant $(p=0.21)$. There was also no significant gender difference in the mean serum $\mathrm{Zn}$ level across age groups $(p>0.05)($ Table V).
} 


\section{Relationship between serum zinc levels with types of malnutrition.}

The mean serum $\mathrm{Zn}$ levels was significantly low among all the clinical types of malnutrition $(p=0.0001)$, with the lowest levels observed among children with Oedematous malnutrition $(12.8 \pm 3.0 \mu \mathrm{mol} / \mathrm{L})$, when compared to that of the controls $(15.8 \pm 1.9 \mu \mathrm{mol} / \mathrm{L})$ the difference was significant $(p=0.0001)$. Children with mild wasting had the highest mean serum $\mathrm{Zn}$ levels $(14.2 \pm 3.3 \mu \mathrm{mol} / / \mathrm{L})$ (Table VI).

\section{Socio-economic class of the parents of the subjects and the controls}

$233(85.0 \%)$ of the children with malnutrition were from lower-socio-economic class (SEC), 34(12.0\%) in the middle SEC, and only $8(3.0 \%)$ were from upper SEC, while for the controls 53(19.0\%) of the children were from the lower SEC, 151(55.0\%) from the middle SEC, and $71(26.0 \%)$ were from the upper SEC. The subject's parents were of a lower-socio-economic class compared to the controls $\left(\mathrm{x}^{2}=815.6, \mathrm{df}=6, p=0.0001\right)$.

\section{DISCUSSION}

This study's finding is in consonance with previous studies $(28,29)$ that there is no gender difference in the prevalence of malnutrition, but it is in contrast to the findings of Olwedo et al (30) in Uganda and Emina et al (31) in republic of Congo which suggested that malnutrition is more prevalent among boys than girls.

The predisposition of male children to malnutrition may be due to the fact that female children receive more attention from the parents (32). Boys are rare at home; they tend to be active, running around the neighborhood compared to female children who eat whatever small feeds their mother give them since they are always with them at home (32). There are inconsistent findings in relation to the prevalence of malnutrition in relation to gender, some studies showed that female children are more at risk of malnutrition than male children (33). Inequality between girls and boys can take many different forms, one of which could be neglect of health, nutrition and other needs of girls that influence survival of the girl child (33). Oedematous malnutrition was encountered in $33.8 \%$ of the recruited subjects, which was the most prevalent form of malnutrition found in this study, a finding in keeping with that of Madondo et al (34). In South Africa, severe wasting was observed in $29.8 \%$ of the subjects in this study, which was more than mild, and moderate wasting respectively. Similar findings were reported by other researcher (34). Severe wasting is indicative of acute malnutrition, which may result from a number of factors in the studied population such as reduced food intake and availability, as well as illnesses (34). Reduced anti-oxidants status in malnourished children such as $\mathrm{Zn}$ has also been reported to be from oxidative stress as a result of increased generation of reactive oxygen species. As antioxidants are involved in fighting against oxidative stress some amount might be exhausted $(35,36)$.

The low mean serum $\mathrm{Zn}$ levels among children with malnutrition has been attributed by some workers to low dietary intake, poor bioavailability, mal-absorption and increased losses due to diarrhoea along with lack of breastfeeding $(12,13,17)$ as found in this study which showed only $5.0 \%$ of the children with malnutrition were exclusively breastfed.

The mean serum $\mathrm{Zn}$ level $(13.5 \pm 3.3 \mu \mathrm{mol} / \mathrm{L})$ of malnourished children observed in this study was similar to $13.2 \pm 1.7 \mu \mathrm{mol} / \mathrm{L}$ reported among pre-school Indonesian children, (37) but higher than $7.8 \pm 0.17 \mu \mathrm{mol} / \mathrm{L}, 9.0 \mu \mathrm{mol} / \mathrm{L}$ and $9.9 \pm 0.96 \mu \mathrm{mol} / \mathrm{L}$ reported respectively among malnourished preschool and school age children in Faisalabad in Pakistan, (38) stunted Cambodian infants and toddlers, (39) and among malnourished children in Ankara, Turkey (40).

The zero prevalence of $\mathrm{Zn}$ deficiency recorded in this study was not in consonance with previous studies $(39,40,41)$ though data on prevalence of $\mathrm{Zn}$ deficiency among Nigerian children with malnutrition is lacking to the best of investigator's knowledge, most of the Nigerian studies determine mean serum $\mathrm{Zn}$ levels not prevalence of $\mathrm{Zn}$ deficiency among children with malnutrition. Some studies reported prevalence of $3.2 \%$ among chronically malnourished Indonesian children, (37) while other studies reported high prevalence of $\mathrm{Zn}$ deficiency, prevalence of $28.0 \%$ for $\mathrm{Zn}$ deficiency was reported among malnourished Indian children, (42) Anderson et al reported prevalence of 73.2\% among stunted Cambodian children and infants (39). Mushi et al reported a prevalence of $74.0 \%$ following a study on 66 Tanzanian children recovering from severe PEM (41). It followed that $\mathrm{Zn}$ deficiency was not observed in this study using WHO cut off value for zinc deficiency in under five years of age (27) and despite the fact that the gold standard method of $\mathrm{Zn}$ analysis 
(Atomic Absorption Spectrophotometric method) was used for determining the serum $\mathrm{Zn}$ status of the recruited children, which was also the method used by the above mentioned studies. Many studies have stressed that serum $\mathrm{Zn}$ level is not a good indicator of overall $\mathrm{Zn}$ status as $98.0 \%$ of body's zinc is intracellular (14). Serum $\mathrm{Zn}$ levels can be found within normal limits even in individuals with low body stores due to a strict homeostatic control $(43,44)$, however despite these limitations, serum $\mathrm{Zn}$ level is still the most widely used biomarker of $\mathrm{Zn}$ status since other biomarkers also showed limitations in addition to major difficulties in execution (45).

The prevalence and burden of $\mathrm{Zn}$ deficiency is quite different all over the world.(42) Reasons for variation in the prevalence of $\mathrm{Zn}$ deficiency worldwide could be due to diversity of nourishment sources, regional variation and difference in ethnic diets.(46) The reasons for the variation in the prevalence of $\mathrm{Zn}$ deficiency may be due to differences in cut off values for $\mathrm{Zn}$ deficiency used in many studies ranged from $70-100 \mu \mathrm{g} / \mathrm{dl}(10.71-15.3 \mu \mathrm{mol} / \mathrm{L})$ as against $65 \mu \mathrm{g} / \mathrm{dl}(9.9 \mu \mathrm{mol} / \mathrm{L})$ used in this study which is the WHO cut off value for Zn deficiency in children less than 5 years of age.(27)

The present study demonstrated that malnourished children aged 2 to 3 years had lowest mean serum $\mathrm{Zn}$ levels. Similar finding was also reported by earlier researcher in relation to zinc (47). This is because this age coincides with age of weaning and peak age of occurrence of malnutrition (25). After weaning, children derive nutrition from a monotonous habitual diet, depending heavily on cereals with little nutritious accompaniment $(35,47)$.

This study like other previous studies showed no significant relationship between serum $\mathrm{Zn}$ levels and gender among children with malnutrition (48-49) and in well-nourished children.(50) The lowest serum Zn levels was observed among children with oedematous malnutrition a finding similar to previous studies (13,17,51-53). Low serum $\mathrm{Zn}$ levels among children with oedematous malnutrition could be attributed to hypo-albuminemia, as albumin provides majority of the binding sites for zinc in plasma (17). Other reasons for the low serum $\mathrm{Zn}$ levels in oedematous malnutrition are dilution by the increased extracellular fluid which contributes to lower plasma $\mathrm{Zn}$ levels (53) coupled with intake of food low in $\mathrm{Zn}$ as well over utilization during infection (43). The mean serum zinc vary with severity of wasting, with the lowest value among children with severe wasting, a finding similar to that of Anurhadha et al $(16,54)$. Katja et al (55) showed no relationship between serum zinc levels and wasting. Low serum zinc levels in children with severe wasting may result from increased gastrointestinal losses, increased need for rapid growth and high phytate in the diet.

It is concluded from our findings in this study that prevalence of Zn deficiency may not be a significant health problem in the study area. We recommend that such study be carried out in other regions of the country to affirm our findings.

Acknowledgement: We acknowledge the kind support of the parents and care givers of the children who participated in this study, the management of UDUTH for granting ethical clearance and partial funding this study and colleagues who contributed in one way or the other to its success.

Source of funding: Partly funded by UDUTH management and corresponding author

Conflicts of interest: The authors declares no conflicts of interest.

\section{REFERENCES}

1. Ahmed T, Michaelsen KF, Frem JC and Tumvine J. Malnutrition Report of the FISGHAN Working Group. J Pediatr Gastroenterol Nutr 2012;55:626-31.

2. UNICEF. Improving child nutrition. The achievable imperative for global progress. New York, UNICEF 2013.

3. World hunger problems facts, figures and statistics available at http // www.worldhunger.org > 2015-world-hun accessed online $15^{\text {th }}$ September 2016.

4. Oyedeji G.A. Is it well with the Nigerian child? Obafemi Awolowo University Ile Ife, Nigerian inaugural lecture series 171.2000; 13

5. UNICEF State of the World's children: Official publication of the United Nations. 2005; 85-8.

6. Reddy V. Protein-Energy Malnutrition. In: Stanfield P. Diseases of children in the subtropics and tropics 4th ed.1991; 335-57.

7. Pius CM, Josephat MC, Agozie U, Herbert AO, Odutola $\mathrm{O}$ and Aworene TC. Prevalence of malnutrition among pre-school children in South-east Nigeria. Ital J pediatr 2014;40:75.

8. Lawoyin TO. Risk factors for infant mortality in a rural African community. J Roy Soc Health $2000 ; 121: 114-8$ 
9. Gomez F. Malnutrition in Infancy and Childhood with Special Reference to Kwashiorkor. In: Levine ed. Advances in Paediatrics. New York Yearbook 1955; 7:131169

10. Ohiokpehal O, Mbithe DD, Kamau J. Serum zinc levels of School children on a corn soy blend feeding trial in primary school in Suba district Kenya, tropical soil biology and fertility, available at www.biosciencies, elewa.org, accessed $14^{\text {th }}$ September 2016.

11. Hatz C and Brown KH. Assessment of the risk of zinc deficiency in population and options for its control. Food and Nutr Bull 2004; 25:10:91-204

12. Farhan J, Aneela A, Saifullah S, Mohammed A, Nadeem H, Bushra A. Comparison of serum zinc levels between healthy and malnourished children. A.P.M.C 2009; 3 (2): 139-142

13. Savitri T, Neela G, Poonan K. Serum Copper and zinc concentration and their relation to superoxide dimutase in severe malnutrition. Eur J paed 2004; 163:742-744

14. Debayo MB. Zinc. In: Handbook of clinical chemistry, Spectrum Books limited Ibadan, $2^{\text {nd }}$ ed. 2006; 665-667

15. David BM. Zinc. In: Tiez Fundamental of Clinical Chemistry, 5th edition: 2004; 578- 83

16. Anuradha J, Meena V, Agrawal BK. Estimation of serum zinc and alkaline phosphatase in malnourished children. Current Paed Research 2009; 12 (1): 10-12

17. Okolo SN, Okonji M, Ogonna C, Nwosu OK. And Ocheke MD. Serum zinc levels in malnourished pre- school Age attending the Jos University Teaching Hospital, Jos, Plateau state, Nigeria. Sahel Med J 2002; 5(4): 204-6

18. Mohammed MR, Mohammed A, George J. Synergistic effect of zinc and Vitamin A on the biochemical indices of vitamin A nutrition in children. Am J Clin Nutr 2002; 75-92.

19. Nancy F. Krebs MD, Michael H. Normal childhood nutrition and its disorders: In Current Paediatric diagnosis and treatment, $16^{\text {th }}$ ed. 2009; 277-307

20. Ugwuja El, Nwosu KO, Ugwu NC and Okoji M. Serum zinc and Copper levels in malnourished pre- school Age children in Jos, North Central Nig. Pakistan J of Nutr 2007; 6(4): 349-54

21. WHO child growth standards: length/height- for-age, weight-for-age, weight-for-length, weight-for-height and body mass index-for-age: Methods and development. 2006:405

22. Araoye M.O. Sample size determination In: Research Methodology with Statistics for health and social sciences. Nathadex Publishers Sawmill Ilorin2003; 115-21

23. Maziya-Dixon B, Akinyele IO, Oguntona EB, Nokoe S, Sanusi RA and Harris E. Nigeria Food Consumption and survey 2001-2003 Summary Report. International Institute of Tropical Agriculture, Ibadan, Nigeria; 2004.

24. Oyedeji GA. Socio-economic and Cultural Background of Hospitalized Children in Ilesha. Nig J Paed 1985; 12(4): 111-7

25. Ulasi TO, Ebenebe J. Nutritional disorders in children. In: Azubuike JC, Nkanginieme KEO Paediatrics and Child health in the tropical region $2^{\text {nd }}$ ed, Owerri, University of Port Harcourt press 2007; 250-267

26. Kaneko JJ. Determination of minerals in serum and plasma. In: Clinical biochemistry of animals $4^{\text {th }}$ ed. Academic press, New York; 2004:44-6.

27. Bruno B, Ian D, Lena D, Olivier F, Christian H. Conclusions of the joint WHO/ UNICEF/IAEA/ IZINNCG inter agency meeting on zinc status indicators. Food and Nutr Bull 2007; 28 (3): 5480-4.

28. Cartmel E, Natalal H, Francois I, Farara MH, Grahawt L. Nutritional and clinical status of children admitted to the malnutrition ward, Maputo central hospital: A comparison of data from 2001and 1983. J Trop paed 2005; 51:(2): 102-5.

29. Agozie CU, Ngozi SI, Chika IN, Chinyeaka MU, Chinelo AN. Under five Protein Energy Malnutrition admitted at the University of Nigeria Teaching Hospital, Enugu; A 10 year retrospective review. Accessed on line on $14^{\text {th }}$ $\mathrm{S}$ e p t e m b e r $\quad 2016 \quad$ a t http://www.nutrition.com/content/1/1/43.

30. Olwedo MA, Mworozi E, Bachou H, Orach GC. Factors associated with malnutrition among children in internally displaced person's camps, Northern Uganda. Afr Health Sci 2008 ; (8): 24452.

31. Emina JB, Kandala N, Inungu J. The effect of maternal education on child nutritional status in the Democratic Republic of the Congo, Nairobi, Kenya. J Public Health epidemiology2011; 
3(12) 576-92

32. Babatunde Omilola. Pattern and trends of child and maternal nutrition inequalities in Nigeria. 2010; International food policy research institute accessed on line at http://www.ifpri.org/sites/default/files/publicati ons/ifpridp00968.pdf on $18^{\text {th }}$ September 2016

33. Kriti AP, Sanjivani DL, Naik JD, Rajderkar SS. Gender inequality and bio-social factors in nutritional status among under five children attending Anganwadis in an urban slum of a town in Western Maharashtra, India. J Res Med Sci 2013; 18(4): 341-45.

34. Madondo A, Macintyre UE, Ntuli B. Clinical and anthropometric profile of children. South Afr J of child health 2012; 6(4): 123-27.

35. Mary EP. Protein Energy Malnutrition, pathophysiology, clinical consequences and treatment. In: Walker AW, Christopher D, Watkim JB ed. Nutrition in Paediatrics. London. Blackwell Waterson. 2008; 171-84

36. Jelliffe DB. Protein-calorie malnutrition in tropical pre-school children. J Paed 1959; 54: 227-56

37. Werner S, Merzenich M, Rainer G, Shrimpton D. Effects of iron, zinc and vitamin A status of anaemic pre-school children in Indonesia. Public health nutrition, accessed on line on $18^{\text {th }}$ $\mathrm{S}$ e p t $\quad 2016 \quad$ a t http://archives.unu.edu/unupress/food/v184e/c h1.htm.

38. Farhan J, Aneela A, Saifullah S, Mohammed A, Nadeem H, Bushra A. Comparison of serum zinc levels between healthy and malnourished children. A.P.M.C 2009; 3 (2): 139-42.

39. Anderson VP, Jack S, Monchy D, Hem N, Hok P, Balley $\mathrm{KB}$ et al. Co- existing micronutrients deficiencies among stunted Cambodian infants and toddlers. Asia Pac J Clin Nutr 2008; 17(1): 72-9.

40. Jale E, Ayten MD, Ayhan O, Cardar MD. Hair zinc levels in healthy and malnourished children. Am J Clin Nutr 1978; 31:1172-4.

41. Mushi S. Mumbhi F. and Kitundal J.A. Zinc supplementation in children recovering from severe Protein Energy Malnutrition admitted at Muhimbili National Hospital, DaresalamTanzania. Am J Clin Nutr 2008; 71:256-59.
42. Muzamil S. Stunting and micronutrients deficiencies in malnourished children. J Pak Med Assoc 2010; 60(7): 543-47

43. Diagnosis of zinc deficiency step by step, BMJ publishing group limited 2011, available at htp;/eso.cdn.bmj.com, accessed on $14^{\text {th }}$ September 2016.

44. Solomon NW. Assesment of copper and zinc nutrition in man. Am J of Clin Nutr 1979; 32:856-71

45. Ivan SF, Jullio CD, Helio V, Alceu A, and Alexander A. Zinc serum levels and their association with vitamin A deficiency in preschool children. Jornal de paediastria 2007; 83:6:512-17.

46. Bemnet A, Beyene M, Bereket F, Ketema T, Desalegn W, Gizachew Y et al. Micronutrient levels and nutritional status of school children in North-west Ethiopia. Nutr J 2012; 11:108. Accessed on online www:nutrition. com on $14^{\text {th }}$ September 2016.

47. Ugwuja El, Nwosu KO, Ugwu NC and Okoji M. Serum Zinc and Copper levels in malnourished pre- school Age children in Jos, North Central Nig. Pakistan J of Nutr 2007; 6(4): 349-54

48. Edward B, Edison M and Addy K. Serum zinc status of children with persistent diarrhea admitted to the diarrheoa management unit of Mulago Hospital, Uganda. Afr Health Sci 2003;3 (2): 54-60.

49. Deghanii SM, Katibeh P, Haghighat M, Moravel H, Assad S. Prevalence of zinc deficiency in 318 years old children in Shiraz- Iran. Iran Red Crescent Med J 2011; 13 (1): 4-8

50. Abeer V, Nazir AM, Assad H, Riffat NA. Evaluation of zinc status of preschool children as assessed by hair zinc levels in Punjab Province. Pakistan Armed Forces Medical Journal accessed online at http://www.pafmj.org On $14^{\text {th }}$ September 2016.

51. Smit ZM, Preterius PJ. Serum zinc levels and urinary zinc excretions in South African Bantu kwashiorkor patients. J Trop Pediatr Environ Child health 1964; 9 (3): 105-12

52. Sanstead HH, Shukry AS, Prasad MK, Gabr A, Dabry WJ. Kwashiorkor in Egypt, Clinical and biochemical studies with special references to plasma zinc and serum lactic dehydrogenase. Am J Clin Nutr 1965; 17 (5): 15:103-9. 
53. Barbara EG, Michael HNG. Plasma zinc and the clinical features of malnutrition. Am J Clin Nutr 1979; 32:2490-4.

54. Vasudevan A, Shendumikar N and Kotecha PV. Zinc supplementation in Severe Malnutrition. Indian Pediatrics. 1997; 34:236-37 accessed on line a t cite seerx.is t.p s u. edu>viewdoc.>download on $17^{\text {th }}$ September 2016

55. Katja K, Mohammed AW, Henrik F, Shakuntala H. Acute phase proteins levels, T Trichiuria, maternal education are predictors of serum zinc in a crossectional study in a Bangladeshi children. J Nutr 2006; 136(8): 2622-68 accessed on line at m.in.nutrition.org/content/136/8/2262 on $17^{\text {th }}$ September 2016 
Table I: Age distribution of the subjects and controls.

\begin{tabular}{lll}
\hline Age group months & Subjects n(\%) & Controls n(\%) \\
\hline $6.0-12.0$ & $57(20.7)$ & $60(21.8)$ \\
$12.1-24.0$ & $100(36.3)$ & $90(32.7)$ \\
$24.1-36.0$ & $68(24.7)$ & $53(19.3)$ \\
$36.1-48.0$ & $19(7.0)$ & $34(12.4)$ \\
$48.1-60.0$ & $31(11.3)$ & $38(13.8)$ \\
\hline Total & $\mathbf{2 7 5 ( 1 0 0 . 0 )}$ & $\mathbf{2 7 5 ( 1 0 0 . 0 )}$ \\
\hline
\end{tabular}

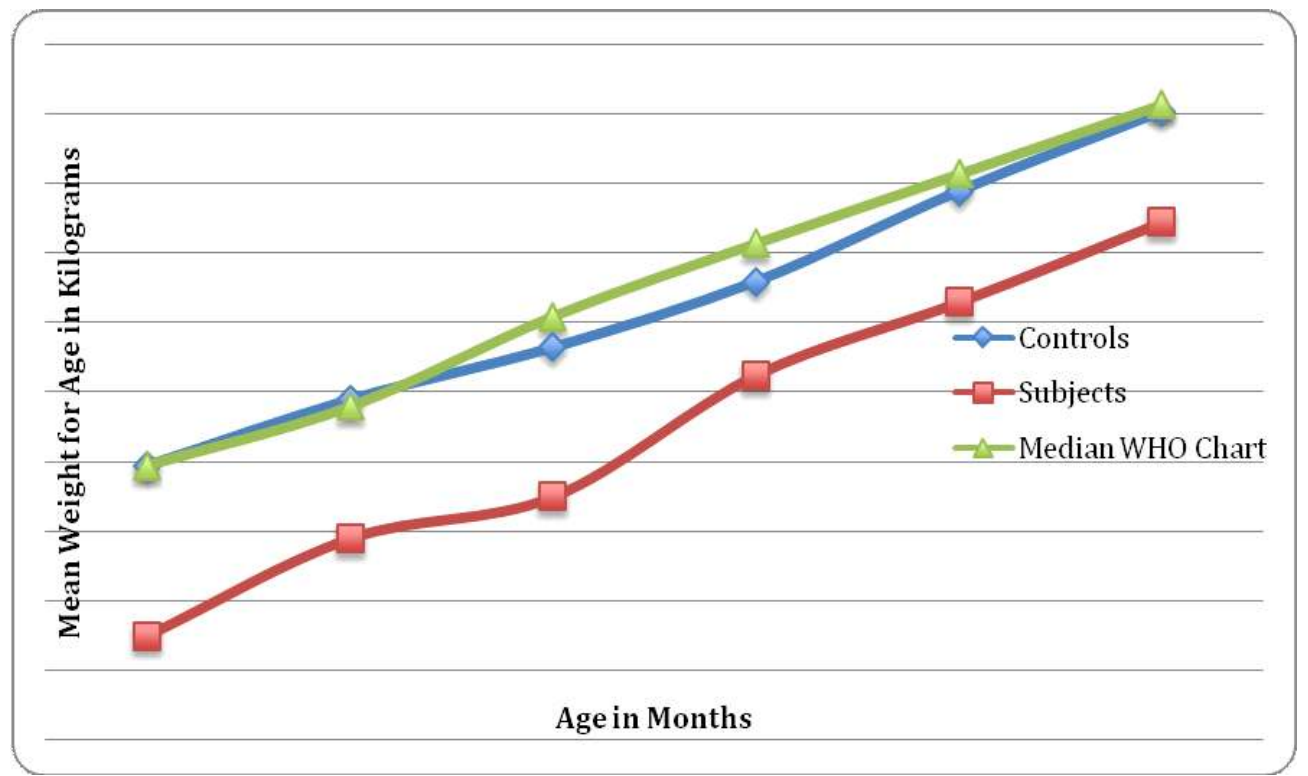

Figure 1: Mean weight for age of the subjects compared with that of the controls and the median values of WHO weight for age growth chart. 
Table II: Distribution of clinical types of malnutrition according to age groups.

\begin{tabular}{llllll}
\hline $\begin{array}{c}\text { Age group } \\
\text { (Months) }\end{array}$ & $\begin{array}{c}\text { Mild wasting } \\
\mathbf{n}(\boldsymbol{\%})\end{array}$ & $\begin{array}{c}\text { Moderate } \\
\text { wasting } \\
\mathbf{n}(\boldsymbol{\%})\end{array}$ & $\begin{array}{c}\text { Severe wasting } \\
\mathbf{n}(\boldsymbol{\%})\end{array}$ & $\begin{array}{c}\text { oedematous } \\
\text { malnutrition } \\
\mathbf{n}(\boldsymbol{\%})\end{array}$ & $\begin{array}{c}\text { Total } \\
\mathbf{n}(\boldsymbol{\%})\end{array}$ \\
\hline $6.0-12.0$ & $4(1.5)$ & $10(3.6)$ & $17(6.2)$ & $26(9.5)$ & $57(20.7)$ \\
$12.1-24.0$ & $5(1.8)$ & $16(5.8)$ & $36(13.1)$ & $43(15.6)$ & $100(36.3)$ \\
$24.1-36.0$ & $6(2.2)$ & $28(10.2)$ & $16(5.8)$ & $18(6.5)$ & $68(24.7)$ \\
$36.1-48.0$ & $2(0.7)$ & $5(1.8)$ & $7(2.5)$ & $5(1.8)$ & $19(6.8)$ \\
$48.1-60.0$ & $13(4.7)$ & $11(4)$ & $6(2.2)$ & $1(0.4)$ & $31(11.3)$ \\
\hline Total & $\mathbf{3 0}(\mathbf{1 0 . 9 )}$ & $\mathbf{7 0}(\mathbf{2 5 . 4})$ & $\mathbf{8 2 ( 2 9 . 8 )}$ & $\mathbf{9 3 ( 3 3 . 8 )}$ & $\mathbf{2 7 5 ( 1 0 0 )}$ \\
\hline
\end{tabular}

Table III: Mean serum zinc levels of children with malnutrition and controls according to age.

\begin{tabular}{|c|c|c|c|c|c|}
\hline \multirow[b]{2}{*}{$\begin{array}{r}\text { Age group } \\
\text { (months) }\end{array}$} & & \multicolumn{4}{|c|}{ Mean serum zinc levels $(\mu \mathrm{mol} / \mathrm{L})$} \\
\hline & & $\begin{array}{l}\text { Subjects } \\
(\mathbf{n}=275)\end{array}$ & $\begin{array}{r}\text { Controls } \\
(\mathbf{n}=275)\end{array}$ & $\mathbf{t}$ & $p$ \\
\hline $6.1-12.0$ & & $13.2 . \pm 2.6$ & $17.1 \pm 3.9$ & 6.0 & 0.0001 \\
\hline & $\mathrm{n}$ & 57 & 60 & & \\
\hline $12.1-24.0$ & & $13.1 \pm 3.0$ & $15.7 \pm 1.7$ & 3.0 & 0.0001 \\
\hline & $\mathrm{n}$ & 100 & 90 & & \\
\hline $24.1-36.0$ & & $\begin{array}{l}12.8 \pm 2.5 \\
68\end{array}$ & $15.3 \pm 2.4$ & 6.2 & 0.0001 \\
\hline $36.1-48.0$ & & $13.8 \pm 3.6$ & $16.1 \pm 0.7$ & 3.8 & 0.0001 \\
\hline $48.1-60.0$ & $\mathrm{n}$ & $\begin{array}{l}14.4 \pm 4.0 \\
31\end{array}$ & $\begin{array}{l}15.8 \pm 1.2 \\
38\end{array}$ & 4.7 & 0.0001 \\
\hline Total & & $13.5 \pm 3.3$ & $15.8 \pm 1.9$ & 10.07 & 0.0001 \\
\hline
\end{tabular}

Table IV: Mean serum zinc levels $(\mu \mathrm{mol} / \mathrm{L}$ ) of children with malnutrition and controls according to the age and gender

\begin{tabular}{|c|c|c|c|c|c|c|c|c|}
\hline $\begin{array}{l}\text { Age } \\
\text { (months) }\end{array}$ & Subjects & $\begin{array}{c}\text { Males } \\
\text { Controls }\end{array}$ & $\mathbf{t}$ & $P$ & Subjects & $\begin{array}{c}\text { Fema } \\
\text { Controls }\end{array}$ & t & $P$ \\
\hline $6.0-12.0$ & $13.2 \pm 2.6$ & $14.2 \pm 3.4$ & 3.32 & 0.221 & $13.3 \pm 3.0$ & $15.8 \pm 2.2$ & -0.42 & 0.31 \\
\hline $12.1-24.0$ & $15.0 \pm 4.9$ & $14 . \pm 3.0$ & 2.61 & 0.010 & $13.3 \pm 2.7$ & $15.9 \pm 1.5$ & -0.71 & 0.318 \\
\hline $24.1-36.0$ & $12.5 \pm 2.2$ & $13.1 \pm 2.6$ & 0.65 & 0.522 & $13.6 \pm 2.8$ & $15.3 \pm 3.2$ & 1.53 & 0.142 \\
\hline $36.1-48.0$ & $13.3 \pm 2.8$ & $15.2 \pm 3.1$ & 1.54 & 0.155 & $14.2 \pm 4.2$ & $15.6 \pm 1.4$ & 1.51 & 0.163 \\
\hline $48.1-60.0$ & $13.8 \pm 3.0$ & $12.7 \pm 2.5$ & 1.01 & 0.413 & $12.0 \pm 2.8$ & $14.2 \pm 2.0$ & 0.41 & 0.633 \\
\hline Total & $13.7 \pm 3.8$ & $16.1 \pm 2.4$ & 14.0 & 0.0001 & $13.5 \pm 2.8$ & $15.3 \pm 1.5$ & 13.7 & 0.0001 \\
\hline
\end{tabular}


Table V: Mean serum zinc levels ( $\mu \mathrm{mol} / \mathrm{L}$ ) among children with malnutrition according to age and gender.

\begin{tabular}{llllll} 
& $\mathbf{n}=\mathbf{1 3 7}$ & $\mathbf{n}=\mathbf{1 3 8}$ & & \\
\hline $6.0-12.0$ & Mean \pm SD & $13.2 \pm 2.6$ & $13.3 \pm 3.0$ & 0.14 & 0.89 \\
& $\mathrm{n}$ & 34 & 23 & & \\
$12.1-24.0$ & Mean \pm SD & $15.0 \pm 4.9$ & $13.3 \pm 2.7$ & 1.58 & 0.12 \\
& $\mathrm{n}$ & 49 & 51 & & \\
$24.1-36.0$ & Mean \pm SD & $12.5 \pm 2.2$ & $13.6 \pm 2.8$ & -2.36 & 0.08 \\
& $\mathrm{n}$ & 36 & 32 & & \\
$36.1-48.0$ & Mean \pm SD & $13.3 \pm 2.8$ & $14.2 \pm 4.2$ & 0.53 & 0.61 \\
& $\mathrm{n}$ & 8 & 11 & & \\
$48.1-60.0$ & Mean \pm SD & $13.8 \pm 3.0$ & $12.0 \pm 2.8$ & 1.0 & 0.33 \\
& $\mathrm{n}$ & 10 & 21 & & \\
\hline Total & Mean \pm SD & $\mathbf{1 3 . 7} \pm \mathbf{3 . 8}$ & $\mathbf{1 3 . 5} \pm \mathbf{2 . 8}$ & $\mathbf{2 . 9}$ & $\mathbf{0 . 2 1}$ \\
\hline
\end{tabular}

Table VI: The mean serum zinc levels according to types of malnutrition.

\begin{tabular}{lll}
\hline $\begin{array}{l}\text { Clinical types of } \\
\text { Malnutrition }\end{array}$ & $\begin{array}{l}\text { Number of children } \\
\mathbf{n}(\%)\end{array}$ & $\begin{array}{l}\text { Mean serum zinc levels } \\
(\boldsymbol{\mu m o l} / \mathrm{L})\end{array}$ \\
\hline $\begin{array}{l}\text { Control } \\
\text { †Oedematous }\end{array}$ & $275.0(100.0)$ & $15.8 \pm 1.9$ \\
malnutrition & $93.0(33.8)$ & $12.8 \pm 3.0$ \\
Mild wasting & & \\
Moderate wasting & $30.0(10.9)$ & $14.2 \pm 3.3$ \\
†Severe wasting & $70.0(25.4)$ & $13.7 \pm 3.7$ \\
\hline
\end{tabular}

$\mathrm{F}=25.1,(p=0.0001), \dagger=\mathrm{t}=6.99,(p=0.0001), \neq=\mathrm{t}=8.7,(p=0.001)$, $\mathrm{F}=$ one way analysis of variance(ANOVA) 